\title{
The Covid-19 Pandemic and Human Rights-Based Approach to Local Governance in Desa Pakam, Batu Bara, North Sumatra
}

\author{
Majda El Muhtaj ${ }^{1 *}$, Prayetno ${ }^{2}$, Reh Bungana Beru Perangin-angin ${ }^{3}$, \\ M. Fahmi Siregar ${ }^{4}$, Fazli Rachman ${ }^{5}$
}

\author{
${ }^{1}$ Universitas Negeri Medan \\ ${ }^{2}$ Universitas Negeri Medan \\ ${ }^{3}$ Universitas Negeri Medan \\ ${ }^{4}$ Universitas Negeri Medan \\ ${ }^{5}$ Universitas Negeri Medan \\ Email:elmuhtaj.73@gmail.com
}

\begin{abstract}
The subsidiarity principle in conducting local governance system in desa (village) has been adopted by Law No. 6 of 2014 concerning Desa. The law recognizes that Desa has the scale of local authorities and decisions to fully realize the villagers interests. However, in the situation of covid-19 pandemic concerns, Indonesian national government has been striving to prevent and overcome the pandemic and also enacted the emergency policies including economic and legal policies. In addition, for local governments including village must create and re-arrange the prioritized programs to be done effectively. This article examines the capacity of local government of Desa Pakam, Batu Bara, North Sumatra in conducting human rights-based approach to development (HRBA) during the pandemic. This article uses the legal research method and adopts normative juridical approach. Collecting data is gained by the secondary data, namely regulations, textbooks and journals. Beside it, data also obtained by interview with focused group discussion in the field. By using a conceptual framework of HRBA, this article analyses on the strategical ways in the implementation of the prioritized programs related to strengthen the resilience of villagers especially for disadvantage and vulnerable groups who are fully affected by pandemic. Actually, HRBA could improve the resilience for villagers and make comprehensive social protection according to human rights standards and mechanisms.
\end{abstract}

Keywords: human rights, human rights-based approach to Development, desa

\section{INTRODUCTION}

Desa (village) have an important role in supporting the existence of the state and national development. Desa is the main national strength which plays the real role as a buffer for achieving national goals. It is not an exaggeration to opine that the face and performance of the village is the main reflection of the outlook of Indonesia's development. Desa is the important actor of national development to realize the obligation and responsibility of government including the obligation and responsibility of human rights[1].

In its development, now the existence of the village is increasingly strengthened as a subject of government. If for decades the village has been positioned as a subdevelopment of the regional, then through the mandate of Law No. 6 of 2014 concerning Desa (Village Law) is the subject of national development which has a new legal construction[2]. Village authority is very significant because the administration of village government is equipped with the principle of subsidiarity governance[3]. The principle of subsidiarity is the determination of local-scale authority and local decisionmaking for the interest of the village community[3].

Seeing the scope of village authority to positively engineering village development, the mandate of village government obligations is actually highly correlated with the achievement of Indonesia's national goals, namely: 
independence and welfare of villagers. The village authority is regulated in the provisions of Article 18 of the Village Law which reads, "Desa authority includes authority in the field of village government administration, village development implementation, village community development, and village community empowerment based on community initiatives, origin rights, and village customs".

Based on this provision, the village plays a strategic role in strengthening national integrity in an effort to realize the essence of Indonesia's national goals [4]. In the context of Desa development, this correlates with the provisions of Article 78 of the Village Law which affirms the following:

"Village development aims to improve the welfare of the village community and the quality of human life as well as poverty alleviation through the fulfilment of basic needs, development of village facilities and infrastructure, development of local economic potential, and sustainable use of natural resources and the environment."

In this regard, it is important to consider steps to harmonize village development policies which are in line with state goals as the main direction of national development, as described in the national development planning system through Law No. 25 of 2004 concerning the National Development Planning System (NDPS Law) [5] based on the National Long-Term Development Plan[6] and the National Medium-Term Development Plan[7]-[10].

The essence of the national development planning system is synergistic-collaborative development between the organizers of state power and the people. Article 1 Point 3 of the NDPS Law explains this as follows:

"the national development planning system is a unified development planning procedure to produce long-term, medium-term and annual development plans implemented by elements of state administrators and the community at the Central and Regional levels."

In addition, because the village is a government structure with the attribution of power and authority of subsidiarity, it attaches to human rights obligations, specifically the obligation to protect, protect and fulfil human rights[1]. In this framework, basic human rights knowledge and applicable steps for mainstreaming human rights in policies of village development are important to be realized.

It is no exaggeration if this understanding of human rights is relatively good and develops positively among villagers. It is a solution to problems in the village by applying a human rights-based development approach (HRBA). Even, because of the human rights approach in development requires an increasing understanding and awareness of human rights. Certain, it will be more effective to encourage the birth of a democratic governance and development process aimed at improving the human condition [11, p. 125], including at the village level.

The Indonesian government has officially designated the COVID-19 pandemic as a national disaster through Presidential Decree No. 12 Year 2020 [12]. During the COVID-19 pandemic, of course, the face of development in the world, including Indonesia, has serious implications [13]. The planning and implementation of the national development agenda are faced with new realities which demand fundamental changes. This will not only have implications for changes in budget items, but also for emphasizing policy objectives that have to be rationalized into a new orientation which is more suggestive and considerate [14]. Strengthening the policy foundation, the Government of Indonesia issues emergency policies which contain policy adaptations that must be implemented, including those that have an impact on national policies at the regional and village government levels [15].

The national institutional framework strengthens support to prevent the COVID-19 pandemic [16]. Correspondingly, an analysis of the reorientation of national development policies is carried out in the form of prioritizing cash social assistance to weak communities affected by the pandemic [17]. Additionally, the rationale for national development is also directed at real support for the growth and empowerment of the real economic sector of the community at the level of small, micro and medium enterprises. Participation in village development through community involvement through labour-intensive programs is maximized to reduce the impact of unemployment in the aftermath of the pandemic that hit the trade and industrial business sectors. Priority for the using of village funds is directed at responding to the COVID-19 pandemic [18], [19].

The COVID-19 pandemic and village development have relevance for academic studying and interest to be exploring [20]. The national government structure closest to the community is the village government organization. Empirically, villages in Indonesia have high social modalities [21, pp. 12-13]. Naturally, the functionalization of the power and authority of the village government which can strengthen its capacity amidst the rationalization of national development policies is nonnegotiable as an absolute necessity [22]. However, capturing of paradigm the participatory and inclusive village development in a situation of the COVID-19 pandemic is an important part of the unique and interesting character of village government leadership, especially in Pakam Desa, Medang Deras District, Batu Bara Regency, North Sumatra Province. 


\section{LITERATURE REVIEW}

Desa (eng: village) is a legal community unit within a territorial area that is authorized to regulate and manage the government, the interests of the local community based on community initiatives, origin rights, and/or traditional rights autonomously which are recognized and respected in the government system of the Republic of Indonesia [3]. Based on the Law of the Republic of Indonesia Number 6 of 2014 concerning Villages, the government of desa is organized based on the principle of subsidiarity [3], [23]-[25]. Based on these principles, the COVID-19 response policy must be carried out by upholding the applicable laws and regulations [26], [27]. Therefore, policies for handling COVID-19 must be carried out in harmony by mainstreaming efforts to fulfil, protect, and promote human rights [27]-[29].

Desa is the subject of national development which is in the construction of the new law as positive engineering to build the independence and welfare of the village community [3], [27]. The implementation of desa government authority has reciprocity with the Vienna Declaration and Program of Action in 1993 which places the position of the individual as the subject of development [27], [30]. Village development policies must pay attention to the principles of the human rightsbased approach to the development, including handling impacts and preventing the spread of COVID-19 [27], [31]-[35].

The human rights-based approach is based on the four principles of inalienability, indivisibility and interdependence of human rights; empowerment and participation; equality and non-discrimination; and accountability [11], [36], [37]. The human rights-based COVID-19 handling carried out by the desa government places residents as the subject of protection and handling from the spread of COVID [36], [38], [39]. Human rights are key in shaping the response to the COVID-19 pandemic, both for a public health emergency and for the wider impact on people's lives and livelihoods[38]. The government's policy to respond to COVID-19 based on human rights has resulted in better handling policies in defeating the pandemic, ensuring health care for everyone and maintaining human dignity[38].

\section{METHODS}

This paper uses legal research methods, namely research on law in its form as a product of regulations, institutions and law enforcement. According to Morris L. Cohen and Kent C. Olson legal research is an essential component of legal practice (an essential component of the practice of law) [8, p. 1]. For Cohen and Olson, legal research is a process of identifying, determining and analysing the legal provisions that apply in society [40]. The approach used is the legal norms mandated in the laws and regulations governing the Desa. The data collection uses secondary legal sources, namely references to law books, journals and legal dictionaries. To support data acquisition, data collection techniques were used through interviews in the form of focus group discussions. Qualitative data analysis was used to examine the conceptual framework of human rightsbased development that became the international reference and guideline and its implementation in the government of Pakam Desa, Batu Bara.

\section{RESULTS AND DISCUSSION}

\subsection{Human Rights-Based Development During the COVID-19 Pandemic}

The conceptualization of a human rights-based development approach (HRBA) is known as a form of a development approach that is accepted by the international community. HRBA is a framework that integrates the norms, principles and standards and goals of the international human rights system into development planning and processes. RBA can be said to be an integral part of development itself. As is well known, the alienation of development with the existence and future of society, especially for groups vulnerable to human rights violations, has led to far from the benefits of development for achieving the goals of human welfare and dignity.

The basis of RBA lies in four main elements, namely inalienability, indivisibility and interdependence of human rights; empowerment and participation; equality and non-discrimination; and accountability.

Actually, the point of contact for HRBA, through these four principles, is attempted to reach a maximum of four groups, namely: first, most vulnerable groups; second, root caises; third, rights-holders and dutybearers; and fourth, empowerment [41]. In other words:

"in this regard, it is crucial to keep in mind that other obligations must be considered as well, at all three levels, such as the duty to establish norms, procedures and institutional machinery essential to the realization of rights; and the duty to comply with human rights principles such as non-discrimination, transparency, participation and accountability [42, p. 26]".

This is important emphasized because development must be aimed at achieving the will and welfare of the community. The main direction of HRBA aims to influence accountability and balance in the development process, between the people as rights-holders with the state as a duty bearer which is obliged to fulfil the rights of its citizens (rights-holders).

This approach provides broad space and opportunity for the community, especially to participate, contribute and enjoy the results of development in all aspects that support the fulfilment of the values of respect and promotion of human rights, both civil and political rights; 
and economic, social and cultural rights [43, p. 2]. Corruption is certainly difficult to develop if access to information, freedom of opinion, participation and accountability is opened and easily obtained by the public. A human rights-based approach will have the power to protect development strategies from the detrimental effects of corruption.

Based on the state's constitutional obligations, it contains at least two important elements in obligations, namely: first, obligation to conduct; and second, obligation to result [43, p. 29]. The first obligation requires the state to take certain steps to carry out the fulfilment of a right. For example, the state undertakes the construction of schools, ensures the availability of teachers and educational facilities and allocates a measurable budget [43].

The second obligation requires states to implement and meet measurable substantive standards. For example, the state designs a program in the next five years that all people will have access to nine years of basic education [43]. The important thing that should be emphasized, as the bearer of responsibility, the state is required to carry out and fulfil all obligations at once and immediately. If these obligations fail, then the state has been said to have committed human rights violations.

In the COVID-19 pandemic situation, the implementation of the HRBA concept is interesting to observe. HRBA actually provides maximum protection space for groups vulnerable to human rights violations, including environmental degradation. The importance of HRBA in overcoming COVID-19 puts human rights standards and mechanisms in development policies, including policies to overcome the adverse effects of the COVID-19 pandemic. The details are as follows:

"A human rights-based approach to the COVID-19 crisis is also needed to address its unequal impacts on the poor, vulnerable and marginalized and its underlying drivers, including environmental degradation. The following key messages on human rights, the environment and COVID-19 highlight essential human rights obligations and responsibilities of States and others, including businesses, in addressing and responding to the COVID-19 crisis [44]”.

\subsection{Participatory and Inclusive Pakam Desa Development}

The COVID-19 pandemic has been deeply felt by the government and the community of Pakam Desa, which is located in Medang Deras District, Batu Bara Regency, North Sumatra Province. Pakam Desa is one of 21 villages within the jurisdiction of the Medang Deras subdistrict. Pakam Desa has 7 hamlets out of 148 hamlets with population of 3434 people from 55,030 people of the total population of Medang Deras Sub-district. The total area of Pakam Desa is $1.86 \mathrm{~km} 2$ or $2.84 \%$ of the total $65.47 \mathrm{~km}^{2}$ area of Medan Deras District. The distance from Pakam Desa to Medang Deras District is $16.65 \mathrm{~km}^{2}$ with a travel time of 15-20 minutes by motorbike [22].

In the midst of the pandemic, the Pakam Desa government continues to try to rationalize development plans and policies. Desa development programs have serious implications with the presence of the COVID-19 pandemic. Based on the guidelines and directions of the Regent of Batu Bara Regency, the COVID-19 pandemic condition must be faced rationally and with a good attitude in carrying out health protocols. In addition, community independence must be encouraged through mutual cooperation so as to strengthen the growth of the community's economic sector. Within that framework, Social assistance from the central government, provincial government, district government and the allocation of village funds is an important concern for the development program in Pakam Desa.

It is recognized that the management of social assistances has not yet been able to run properly and evenly. Social assistances from the central and regional governments, apart from being felt to be very helpful for people affected by the pandemic, has in fact caused misadministration due to invalid data management. Information on social assistance is often asked by the community directly to the Pakam Desa office. As long as the coordination of the assistance goes well, the Pakam Desa apparatus continues to serve and explain about the assistance in question. There are many types of social assistance which are not distributed in the village, but other government offices such as post offices and banks.

The pandemic condition requires Pakam Desa to manage village funds by referring to the policies of the central government and local governments. Maximizing village development with village funds in 2020 of Rp. 769 million, the disbursement of which was carried out in several stages, was dominated by the interests of providing Direct Cash Assistance. This national policy is intended for distribution to the weak. To support the absorption of labour in the village, the policies of the physical development program in Pakam Desa are carried out through a labour intensive program. Through gotong royong (mutual cooperation), the community is involved in planning and construction work, such as repairing street lighting, building and paving roads as well as repairing and cleaning houses of worship and community settlements in several hamlets.

To anticipate the spread of COVID-19, village funds were used to provide hundreds of masks which were distributed to all elementary school and madrasah (Islamic school) students in Pakam Desa. The development initiative in Pakam Desa was carried out independently and participatively because the pandemic had implications for the labyrinthine atmosphere in the community. Community participation, especially 
traditional leaders, religious leaders, community leaders, youth, youth and women are encouraged to collaborate well. Innovation of development programs in Pakam Desa is carried out by looking at the reality of community needs during the pandemic. Village funds are well managed and open. Village officials are able to work well, especially ensuring services to the community during the pandemic. Training and socialization in the form of counselling and skills training for community members are still being carried out, both in collaboration with the government, as well as associations and universities.

In this regard, the village as a government actor has a strategic position to ensure the planning and implementation of national development. The basis of authority and the attribution of power possessed by the village government has a strong legal basis at the level of national legislation. Systematically, development policies in villages are actually coherent with the achievement of national development goals. As an actor of the Indonesian government, the village has the position, authority and attribution of power to realize the government's human rights obligations. It is no exaggeration to say that the village is actually a reflection of the adaptation of national human rights policies which are realized at the level of public services closest to the community. The accentuation of village development is a pressing point for fair, open, participatory and inclusive national development.

The form of national responsibility in achieving Sustainable Development Goals (SDGs) is increasing national capacity for the achievement of SDGs goals, as mandated through Presidential Decree No. 59 of 2017 concerning the Implementation of the Achievement of the SDGs [45]. The achievement of the SDGs has a strong relationship with the realization of human rights obligations [46], [47]. The government's commitment to the SDGs is marked by alignment with national development plans, both long-term and medium-term, marked by national and regional actions. In relation to the pandemic, the realization of the SDGs requires optimizing the collaboration of government and community elements [48].

Within that framework, participatory development in Pakam Desa reflects applicable steps that can be carried out with participatory planning, implementation and evaluation. Emphasis on the protection aspect of vulnerable groups, such as children, women and persons with disabilities during the pandemic is a necessity. The Pakam Desa Government, from the beginning, was highly committed to realizing its presence, role and responsibility to build quality of life and empower the community in an inclusive manner. The active participation of development policymakers during the pandemic does not ignore the importance of rationalization and re-orientation of human rights-based policies.

The village is an important locomotive for the realization of the government's human rights obligations. In the midst of a pandemic, collaboration and innovation in development programs must be carried out fairly and without discrimination. The spirit of collaboration and innovation in Pakam Desa emerged from the various initiatives of the Pakam Desa Government. Realizing that this pandemic condition poses a very bad risk for health and especially for the survival of the community, the Pakam Desa Government makes maximum efforts to explain and involve all elements of policy makers to take progressive steps to realize the village development agenda. There is a fundamental change from the initial plan of the village development program, however, it is believed that the next fundamental change will be addressed by generating collaborative and innovative ideas. The involvement of many external sectors, including the private sector and academia, facilitates the realization of village development achievements.

However, sustaining the importance of sustainable participatory and inclusive development of Pakam Desa is important to be addressed with policies at the local government level that are responsive and progressive. Advocating the interests of fulfilling the basic rights of the community, especially vulnerable groups, requires the presence of a policy paradigm that favours affirmative steps that can be monitored and evaluated openly. Supervision support at the sub-district and district levels as well as the significant roles of village assistants helped strengthen the creation of community resilience in Pakam Desa in the midst of a pandemic.

\section{ACKNOWLEDGMENTS}

Thank you to all parties involved in the research and writing of this article. Especially Universitas Negeri Medan which has been funded the research. We also thank all elements of Pakam Desa who cooperate in helping to collect the research data. We wish the results of the research in this article beneficial to humanity.

\section{REFERENCES}

[1] I. Junaenah and L. Sungkar, "Model Panduan Kriteria Desa Peduli Hak Asasi Manusia dalam Konteks Jawa Barat," PADJADJARAN J. Ilmu Huk. (Journal Law), vol. 4, no. 3, pp. 493-514, Jan. 2017, doi: 10.22304/PJIH.V4N3.A4

[2] Kushandajani, "Implikasi UU Nomor 6 Tahun 2014 Tentang Desa Terhadap Kewenangan Desa," Yustisia, vol. 4, no. 2, pp. 369-396, 2015, doi: 10.20961/yustisia.v4i2.8656.

[3] Undang-Undang Republik Indonesia Nomor 6 Tahun 2014 tentang Desa. 
[4] R. Timotius, "Revitalisasi Desa dalam Konstelasi Desentralisasi Menurut Undang-Undang Nomor 6 Tahun 2014 tentang Desa," J. Huk. Pembang., vol. 48, no. 2, pp. 323-344, Sep. 2018, doi: 10.21143/JHP.VOL48.NO2.1666.

[5] Undang-Undang Republik Indonesia Nomor 25 Tahun 2004 tentang Sistem Perencanaan Pembangunan Nasional.

[6] Undang-Undang Republik Indonesia Nomor 17 Tahun 2007 tentang Rencana Pembangunan Jangka Panjang Nasional Tahun 2005-2025.

[7] Peraturan Presiden Republik Indonesia Nomor 7 Tahun 2005 tentang Rencana Pembangunan Jangka Menengah Nasional Tahun 2004-2009.

[8] Peraturan Presiden Republik Indonesia Nomor 5 Tahun 2010 tentang Rencana Pembangunan Jangka Menengah Nasional Tahun 2010-2014.

[9] Peraturan Presiden Republik Indonesia Nomor 2 Tahun 2015 tentang Rencana Pembangunan Jangka Menengah Nasional Tahun 2015-2019.

[10] Peraturan Presiden Republik Indonesia Nomor 18 Tahun 2020 tentang Rencana Pembangunan Jangka Menengah Nasional Tahun 2020-2024.

[11] F. Sagasti, "A Human Rights Approach to Democratic Governance and Development," in Realizing the Right to Development: Essays in Commemoration of 25 Years of the United Nations Declaration on the Right to Development, vol. 23, no. 4, New York and Geneva: United Nations Publication, 2013, pp. 125-136.

[12] Keputusan Presiden Republik Indonesia Nomor 12 Tahun 2020 tentang Penetapan Bencana Nonalam Penyebaran Corona Virus Disease 2019 (COVID-19) Sebagai Bencana Nasional.

[13] Z. Khazaei et al., "COVID-19 Pandemic in the World and its Relation to Human Development Index: A Global Study," Arch Clin Infect Dis, vol. 15, no. 5. pp. 1-5, Aug. 15, 2020, doi: 10.5812/archcid.103093.

[14] Peraturan Menteri Keuangan Republik Indonesia Nomor 40/PMK.07/2020 tentang Perubahan Atas Peraturan Menteri Keuangan Republik Indonesia Nomor 205/PMK.07/2019 tentang Pengelolaan Dana Desa.

[15] Undang-Undang Republik Indonesia Nomor 2 Tahun 2020 tentang Penetapan Peraturan Pemerintah Pengganti Undang-Undang Nomor 1 Tahun 2020 tentang Kebijakan Keuangan egara dan Stabilitas Sistem Keuangan Untuk Penanganan Pandemi Covid-19 dan/atau dalam Rangka Menghadapi Ancaman yang Membahayakan Perekonomian Nasional dan/atau Stabilitas Sistem Keuangan Menjadi
Undang-Undang.

[16] R. Djalante et al., "Review and Analysis of Current Responses to COVID-19 in Indonesia: Period of January to March 2020," Prog. Disaster Sci., vol. 6, pp. 1-9, Apr. 2020, doi: 10.1016/J.PDISAS.2020.100091.

[17] A. Roziqin, S. Y. F. Mas'udi, and I. T. Sihidi, "An Analysis of Indonesian Government Policies Against COVID-19," Public Adm. Policy, vol. 24, no. 1, pp. 92-107, May 2021, doi: 10.1108/PAP-08-2020-0039.

[18] Peraturan Menteri Desa, Pembangunan Daerah Tertinggal, dan Transmigrasi Republik Indonesia Nomor 6 Tahun 2020 tentang Perubahan Atas Peraturan Menteri Desa, Pembangunan Daerah Tertinggal, dan Transmigrasi Republik Indonesia Nomor 11 Tahun 2019 Tentang Prioritas Penggunaan Dana Desa Tahun 2020.

[19] Instruksi Menteri Dalam Negeri Nomor 3 Tahun 2020 tentang Penanggulangan Corona Virus Disease 2019 (COVID-19) Di Desa Melalui Anggaran Pendapatan dan Belanja Desa.

[20] F. H. Mamonto, T. Wawointana, and G. E. Moningka, "Policy Implementation Direct Cash Assistance Program in Corona Virus Disease (COVID-19) in Tondegesan Village Kawangkoan Sub District," Publik (Jurnal Ilmu Adm., vol. 10, no. 1, pp. 126-138, Jun. 2021, doi: 10.31314/PJIA.10.1.126-138.2021.

[21] B. Kurniawan, Desa Mandiri, Desa Membangun. Jakarta: Kementerian Desa, Pembangunan Daerah Tertinggal, dan Transmigrasi Republik Indonesia, 2015.

[22] Muhammad, H. Iskandar, R. Rasyidin, J. Ahyar, and R. Kurniawan, "Village (Gampong) Owned Enterprises with Local Wisdom Between Opportunities and Threats in The Area Of COVID-19 Pandemic (Research at The Government Environment of Lhokseumawe City)," J. Manaj. Pelayanan Publik, vol. 4, no. 2, pp. 212-228, Feb. 2021, doi: 10.24198/JMPP.V4I2.31650.

[23] A. Fairus, Buku Pintar Tata Kelola Desa dan Kelurahan. Temanggung: Desa Pustaka Indonesia, 2019.

[24] K. Putri, Buku Pintar Kewenangan Desa dan Regulasi Desa. Temanggung: Desa Pustaka Indonesia, 2019.

[25] A. Bebbington, L. Dharmawan, E. Fahmi, and S. Guggenheim, "Local Capacity, Village Governance, and the Political Economy of Rural Development in Indonesia," World Dev., vol. 34, no. 11, pp. 1958-1976, Nov. 2006, doi: 10.1016/j.worlddev.2005.11.025. 
[26] Bima Jati and G. R. A. Putra, "Optimalisasi Upaya Pemerintah Dalam Mengatasi Pandemi Covid 19 Sebagai Bentuk Pemenuhan Hak Warga Negara," SALAM J. Sos. dan Budaya Syar-i, vol. 7, no. 5, pp. 473-484, Apr. 2020, doi: $10.15408 /$ sjsbs.v7i5.15316.

[27] R. B. B. Perangin-angin, F. Rachman, Prayetno, M. F. Siregar, and M. El Muhtaj, "Responses of Communities Affected by the Sinabung Eruption to COVID-19: A Human Rights-Based Review," in Proceedings of the 3rd International Conference on Innovation in Education, Science and Culture, ICIESC 2021, 31 August 2021, Medan, North Sumatera Province, Indonesia, Nov. 2021, pp. 434-439, doi: 10.4108/EAI.31-82021.2313813 .

[28] Undang-Undang Nomor 39 Tahun 1999 Tentang Hak Asasi Manusia.

[29] S. Leckie and A. Gallagher, Eds., Economic, Social, and Cultural Rights: a Legal Resource Guide, Leckie, Sc. University of Pennsylvania Press, 2011.

[30] Vienna Declaration and Programme of Action.

[31] A. Spadaro, "COVID-19: Testing the Limits of Human Rights," Eur. J. Risk Regul., vol. 11, no. 2, pp. 317-325, 2020, doi: 10.1017/err.2020.27.

[32] J. J. Amon, "COVID-19 and Detention: Respecting Human Rights," Health Hum. Rights, vol. 22, no. 1, pp. 367-370, 2020.

[33] M. Broberg and H.-O. O. Sano, "Strengths and Weaknesses in a Human Rights-based Approach to International Development - An Analysis of a Rights-Based Approach to Development Assistance Based on Practical Experiences," Int. J. Hum. Rights, vol. 22, no. 5, pp. 664-680, May 2018, doi: 10.1080/13642987.2017.1408591.

[34] S. Joseph, "International Human Rights Law and the Response to the covid-19 Pandemic," J. Int. Humanit. Leg. Stud., vol. 11, no. 2, pp. 249-269, 2020, doi: 10.1163/18781527-bja10004.

[35] World Health Organization, "Addressing human rights as key to the COVID-19 response," World Heal. Organ. Publ., no. April, pp. 1-4, 2020, [Online]. Available: http://familyplanning2020.org/sites/default/files/ COVID/WHO-2019-nCoV-SRH-Rights2020.1-eng.pdf.

[36] V. Gauri and S. Gloppen, "Human rights-based approaches to development: Concepts, evidence, and policy," in Polity, Oct. 2012, vol. 44, no. 4, pp. 485-503, doi: 10.1057/pol.2012.12.

[37] T. Destrooper, "Linking Discourse and Practice: The Human Rights-based Approach to Development in the Village Assaini Program in the Kongo Central," Hum. Rights Q., vol. 38, no. 3, pp. 787-813, 2016, doi: 10.1353/hrq.2016.0042.

[38] United Nations, "COVID-19 and Human Rights: We are all in this together," New York, 2020. [Online]. Available: https://www.un.org/sites/un2.un.org/files/un_pol icy_brief_on_human_rights_and_covid_23_apri 1_2020.pdf.

[39] S. Wing, "Human Rights Based Approaches to Development: Concepts, Evidence, and Policy," SSRN Electron. J., no. September, 2012, doi: 10.2139/ssrn.1914599.

[40] M. L. Cohen and K. C. Olson, Legal Research. Minnesota: Thomson-West, 2007.

[41] J. K. M. Bosan and T. Martin, Applying a RightsBased Approach: An Inspirational Guide for Civil Society. Denmark: Danish Institute for Human Rights, 2007.

[42] International Council on Human Rights Policy, Corruption and Human Rights: Making the Connection. Switzerland: ICHRP, 2009.

[43] M. S. Firdaus, Pembangunan Berbasis Hak Asasi Manusia: Sebuah Panduan. Jakarta: Collaboration between Komnas HAM with AusAID, 2007.

[44] Human Rights, the Environment and COVID-19: Key Messages.

[45] Peraturan Presiden Republik Indonesia Nomor 59 Tahun 2017 tentang Pelaksanaan Pencapaian Tujuan Pembangunan Berkelanjutan.

[46] S. R. da C. Seixas and J. L. de M. Hoefel, Eds., Environmental Sustainability: Sustainable Development Goals and Human Rights. Oxon: CRC Press, 2021.

[47] M. Kaltenborn, M. Krajewski, and H. Kuhn, Eds., Sustainable Development Goals and Human. Switzerland: Springer Open, 2021.

[48] UNICEF, UNDP, Prospera, and SMERU, Analysis of the Social and Economic Impacts of COVID-19 on Households and Strategic Policy Recommendations for Indonesi. Jakarta: May, 2021. 